\title{
Impacts of Dredging on Fluvial Geomorphology in the Jamuna River, Bangladesh
}

\author{
Md Mosiur Rahman ${ }^{*}$, Md Sazadul Hasan ${ }^{2}$, Moniruzzaman Khan Eusufzai ${ }^{3}$, Md Munsur Rahman ${ }^{4}$ \\ ${ }^{1}$ Institute of Water Modelling (IWM), Dhaka, Bangladesh \\ ${ }^{2}$ Department of Civil Engineering, Stamford University Bangladesh, Dhaka, Bangladesh \\ ${ }^{3}$ River Research Institute (RRI), Faridpur, Bangladesh \\ ${ }^{4}$ Institute of Water and Flood Management (IWFM), Bangladesh University of Engineering and Technology, Dhaka, Bangladesh \\ Email: ^mmn@iwmbd.org
}

How to cite this paper: Rahman, M. M., Hasan, M. S., Eusufzai, M. K., \& Rahman, M. M. (2021). Impacts of Dredging on Fluvial Geomorphology in the Jamuna River, Bangladesh. Journal of Geoscience and Environment Protection, 9, 1-20.

https://doi.org/10.4236/gep.2021.96001

Received: April 17, 2021

Accepted: June 4, 2021

Published: June 7, 2021

Copyright (c) 2021 by author(s) and Scientific Research Publishing Inc. This work is licensed under the Creative Commons Attribution International License (CC BY 4.0).

http://creativecommons.org/licenses/by/4.0/

\begin{abstract}
Jamuna, a major braided river in Bangladesh, has an enormous hydrological impact on the surrounding areas and streams. Erosion and sedimentation in the Jamuna river cause a large flow fluctuation and floods round the year. Bangladesh Water Development Board has initiated a pilot capital dredging project in the Jamuna river in 2011-2012, aiming to guide the flow to reduce the risk of failure of the city area and right guide bundh of the Jamuna Bridge. This study explores the long-term role of dredging on river morphology using erosion-sedimentation numerical modeling approaches. Primary data were employed in numerical models to estimate the erosion-sedimentation and compared outputs with the real-time cross-sectional variation at selected sections along the reach during 2012-2013. The analysis suggested that the rate of sedimentation is higher ( $60 \%$ to $80 \%)$, where the dredging alignment crosses through the existing sandbar/char. Moreover, a cross-section comparison revealed that the channel near Sirajganj Hardpoint shifted towards the left (east) bank, and the channel within the study area developed very fast along the right (west) bank. However, satellite image analysis revealed that the major bankline shifting occurred from 2000 to 2010 and the channel shifting was observed from 2014 to 2018 along the reach, mostly, after the construction of some river training works. The variation of the channel persistence $(40 \%-$ $100 \%)$ selected part of the study area in the channel incidence map, indicating the rapid dynamic behavior of the river morphology. This study showed a good agreement of measured data and simplified empirical relationships to predict the long-term morphodynamic behavior of the braided Jamuna river.
\end{abstract}

\section{Keywords}

Sediment Transport, Erosion, Dredging, Satellite Image, River Morphology 


\section{Introduction}

Bangladesh, a major part of the Bengal basin which is the world's largest delta (Fischer et al., 2017) formed by the alluvial deposits derived from the Himalayans and tectonic interactions and transported through the major rivers i.e., the Ganges, the Brahmaputra, and the Meghna (Sarker et al., 2011; Rogers \& Overeem, 2017). This delta has been considered as one of the most dynamic ones which attribute the highest sediment discharge and one of the three highest water discharges in the world. It was estimated that the Ganges-BrahmaputraMeghna (GBM) systems had been produced the combined mean annual sediment load of 1.0 to $2.4 \mathrm{BT} /$ year, in which the Brahmaputra contributed the highest (390 to $1160 \mathrm{MT} /$ year) (Goodbred et al., 2014; Rahman et al., 2018) which is around $40 \%$ to $50 \%$ of the total incoming sediment in GBM delta. The Brahmaputra river originated from the southern glacier of the Himalaya and was named Jamuna River when it enters Bangladesh (Islam et al., 1999).

The Jamuna river carries high sediment volume and flow discharge (mostly occurs between June and October) causes an uncertain change in the riverbed, bank erosion, bank shifting, flow fluctuations, flooding, etc. in the downstream catchment (Sarker et al., 2014; Valentine et al., 2018). It transports mostly fine, non-cohesive sands and silts, which are easily erodible with more than $30 \mathrm{~m}$ vertical erosion measured during one season (Thompson et al., 2018). Gradually, the overall width of the Jamuna River exhibits an increasing trend and there is a tendency of shifting westwards, especially at the upstream part of the Jamuna River (Team C-BJE, 1991; FAP 1, 1993; FAP 24, 1996).

The Jamuna River is a classic example of a braided river. The discharge and sediments transported from upstream through the river and the fluxes recirculated process within the delta system have direct roles in the physical sustainability of deltaic environments (Rahman et al., 2018). Additionally, being a braided river, the Jamuna River is strongly influenced by high sediment delivery from nearby sources coupled with lower sediment transport capacity due to hydraulic conditions. Moreover, similar rivers are associated with distinct social purposes (i.e., water supply, irrigation, transportation, etc.) which have a very high social impact (Hasan \& Kabir, 2014; Hasan \& Islam, 2010). Natural disasters due to the hydrological process (i.e., erosion, flood) can directly affect human activities (Uddin \& Rahman, 2012) which have a broader impact on economic and social context as well (Ferdous et al., 2019; Mutton \& Haque, 2004). These types of rivers are sensitive to changes in their flood regime or sediment influx and can completely modify their geometry over a few decades (Rahman et al., 2018). The abrupt shifting of river courses of the Jamuna River has long been recognized as a natural problem that needs to be accurately predicted from the riverbed erosion-sedimentation behavior (Elahi, 1991; Chowdhury \& Kabir, 1991).

However, dredging has been proven as an effective process to control the deposited sediment to prevent flooding and make a pathway for the main channel flow 
(Gob et al., 2005; Zinger et al., 2011). The process also allows us to further solve engineering problems related to sedimentation and erosion in rivers, estuaries, and coastal seas (Van Rijn, 2005). A better prediction of erosion-sedimentation scenarios is inevitable to justify the long-term effectiveness of dredging, which could further promote the design strategies based on qualitative and quantitative analysis. Numerical techniques can be implemented using the primary data from the project for the better prediction of the Jamuna river (a braided river) by simplifying the physical process that happened in the real erosion-sedimentation. Primary and secondary data are widely used in the numerical modeling framework along with the hydraulic sediment transport process (Campagnol et al., 2014; Hasan, 2013; Kasprak et al., 2019). Prediction of accurate scour depth and deposition of the braided river is methodologically very challenging because of the variation in simple path-length distribution resulting in over-scouring (Kasprak et al., 2019).

Bangladesh Water Development Board (BWDB) has initiated $20 \mathrm{~km}$ capital dredging on the River Jamuna as a pilot basis to guide the flow away from the west channel into a mid-channel to reduce the risk of failure of the Sirajganj Hard Point and to guide the flow along the middle of the existing char through the Jamuna Bridge (JMB) near the Dhaleswari Offtake. It was hypothesized that an enhanced flow in the main channel with reduced sediment deposition will lower the flood risk and bank failure. The strong correlation among erosion-sedimentation mechanisms that act at different spatial and temporal scales makes modeling the prediction very complex. According to the Flood Action Plan (FAP) (FAP 1, 1993), a significant contribution to the event was demonstrated by the uneven sedimentation-erosion characteristics of the Jamuna river. They proposed the sediment dynamics of this river can be better explained using the depth-velocity and sediment concentration relationships which are identical to any other rivers in the world. Field data-driven numerical modeling approaches can be implemented to extract erosion-sedimentation patterns of important reaches. Additionally, visualization of the landform change over time gives information about the river dynamics which can further verify the appropriateness of the erosion-sedimentation outputs from the numerical analysis. For example, remote sensing (RS), GIS techniques, satellite image analysis, etc. were widely used in the world to understand the spatial and seasonal suspended sediment load variation (Islam et al., 2001), deposition, and erosion characteristics and investigate the morphodynamical behavior of rivers in Bangladesh (Kafi et al., 2018). RS, GIS techniques, and satellite image analysis were implemented in the assessment of bank erosion, channel shifting of the Padma river (Ophra et al., 2018; Billah, 2018). These advanced tools have also been utilized in the analysis of bank erosion-sedimentation of other rivers such as Dharla, Jamuna, and Teesta in Bangladesh (Bose \& Navera, 2018; Ety \& Rashid, 2019; Akhter et al., 2019; Islam et al., 2019). Sediment concentrations and depth were studied in previous studies to investigate the sediment deposition behavior of rivers in India and Vietnam (Kanga et al., 2020; Nardin et al., 2020).

The overarching objective of this study was to explore the long-term dynamics 
of the fluvial morphology at a selected reach in the Jamuna river due to the influence of dredging. Numerical frameworks coupled with the cross-sectional field data comparison and satellite image analysis were implemented to accomplish the following objectives. The erosion-sedimentation at potential data points were predicted using the numerical models, based on the water depth, velocity, and sediment concentration relationships. Quantitative measurements of the selected cross-sectional at the same reach were compared to justify the output of the sedimentation-erosion model prediction. Moreover, the satellite image analysis was demonstrated the long-term morphological evolution of the Jamuna river. This analysis further supported the appropriateness of the numerical modeling approach for the braided Jamuna river. Overall study findings showed a promise to use the considered numerical approaches for predicting the erosion-sedimentation for similar braided rivers.

\section{Study Area}

The Brahmaputra-Jamuna river system is one of the major river systems of Bangladesh. In its origin from Tibet, it is called Tsangpo River where it flows towards the east and then turn right side and enters North-East Region of India. Inside India, the river is named the Brahmaputra, and flowing over relatively flat terrain and passing through Assam, it finally enters Bangladesh at Noonkhawa. Inside Bangladesh, the Brahmaputra is called Jamuna after it crosses the old Brahmaputra offtake at Kholabarichar of Jamalpur district. Following southward direction, the Jamuna river merges with the Ganges at Aricha to form the Padma river on the way to fall into the Bay of Bengal along with the Meghna River. Figure 1 shows the entire Brahmaputra river from its origin up to the Bay of Bengal. The river drains a vast area of the south-central portion of the Tibetan plateau above the Ganga basin, the south-eastern portion of Tibet, the Patkai-Bum hills, the northern slopes of the Meghalaya hills, the Assam plains, and the northern portion of Bangladesh. The total length of the river from its source up to the Bay of Bengal is $2850 \mathrm{~km}$. Inside Bangladesh (Khan et al., 2014), the Brahmaputra river covers $240 \mathrm{~km}$ from Noonkhawa to Aricha where the existing

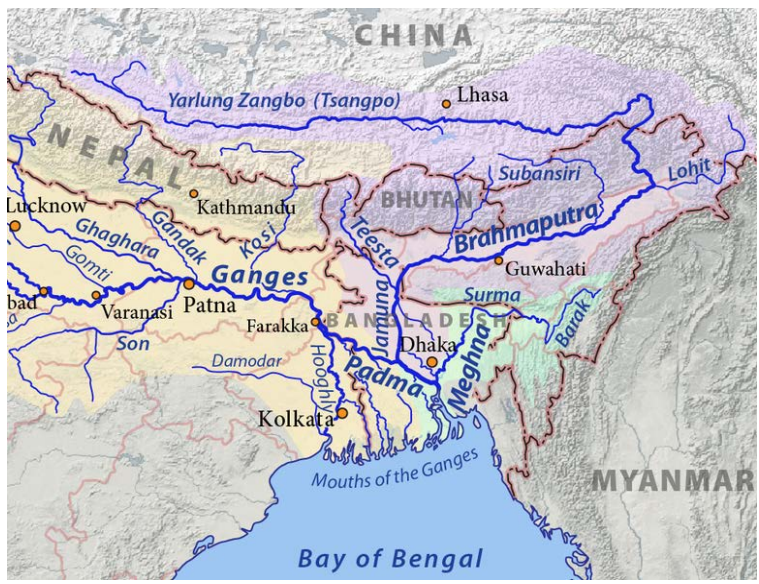

Figure 1. The Brahmaputra-Jamuna river system. 
Bangabandhu Bridge is located at around $160 \mathrm{~km}$ chainage starting from Noonkhawa.

A $20 \mathrm{~km}$ reach of the Jamuna river was primarily selected for this study. Braided channels are rarely in a steady-state and are indicative of a valley bottom still actively undergoing construction (Sambrook et al., 2006). Moreover, rivers can shift from other forms to a braided pattern when human activities accelerate sediment delivery processes. Thus, specifically nine points in five cross-sections (details in Figure 2) in the Jamuna river, located between (easting (m), northing (m)) 471,359, 706,953, and 480,202, 697,014 were considered for the data collection and analysis.

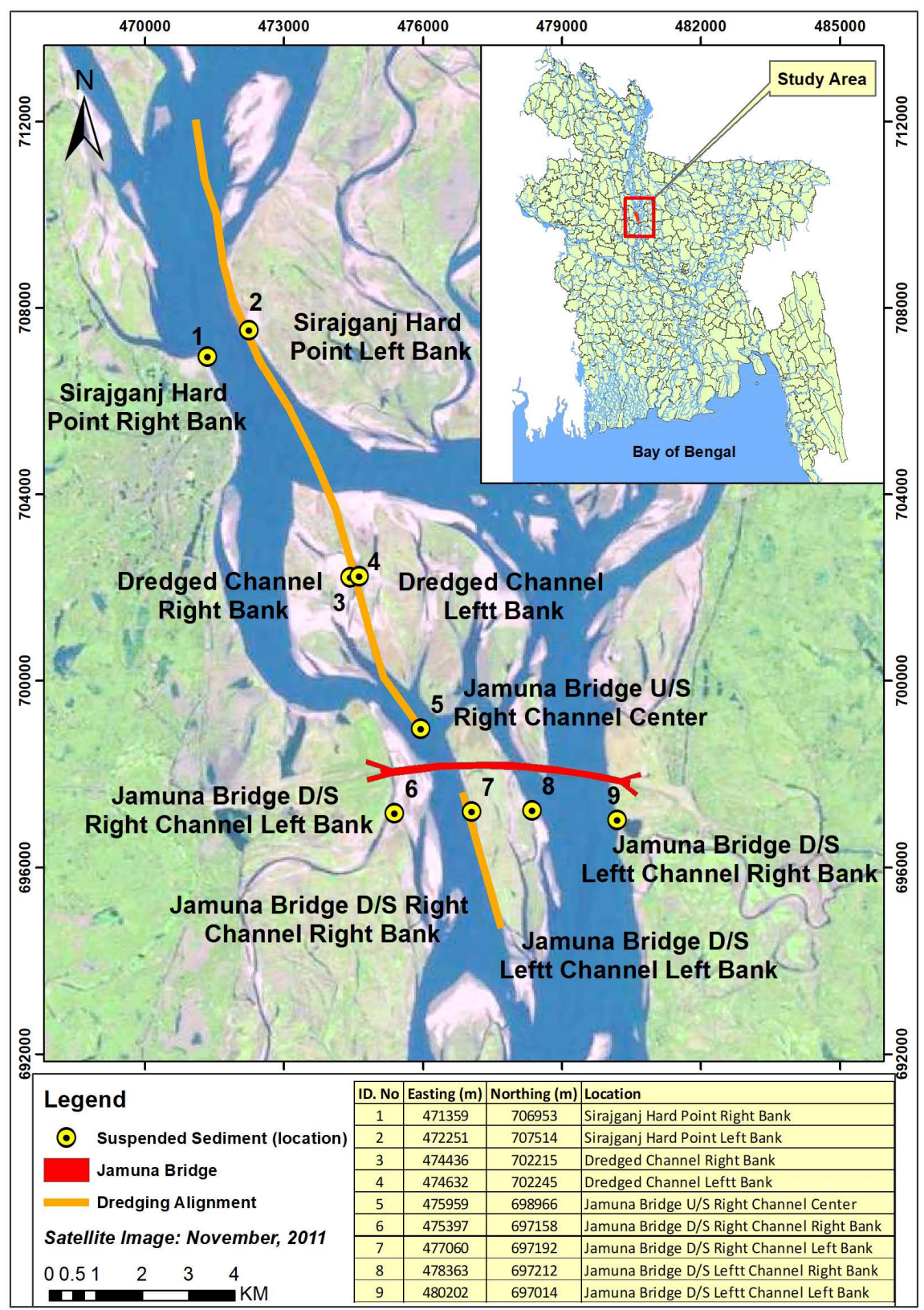

Figure 2. Study location and data points (1 to 9) of the Jamuna river. 


\section{Methodology}

The analysis of this study was carried out based on secondary data. Hydrometric data as sediment concentration, water depth, and depth average velocity at the selected locations were collected from the Institute of Water Modelling and Bangladesh Water Development Board. Moreover, cross-sections of the Jamuna River of four different years $(2010,2011,2012$, and 2013) and satellite images of the study reach from 2000 to 2018 were analyzed.

\subsection{Numerical Estimation of Erosion and Sedimentation}

To identify the erosion and deposition reach within the study area as well as predicting the sedimentation process on a riverbed, two numerical methods were used recommended in the Final Report, Annex-5, Morphological characteristics, FAP 24, November 1996 (FAP 24, 1996). These methods were classified as Method-I (depth-velocity relationship) and Method-II (depth-velocity and sediment concentration relationship). Using those methods collected sediment concentration at the 9 selected locations were duly analyzed and compared with the observed cross-sections. The overall method for analyzing the data of this study is discussed in the following subsections.

\subsubsection{Method-I (Depth-Velocity Relationship)}

This short-term prediction method will be useful for estimating the requirement of dredging and it can assist in deciding to identify the location of dredging work. A simpler prediction method for riverbed level changes was made visually, Peters in 1988 (FAP 24, 1996). According to the equation, the net erosion and net sedimentation in the downstream direction can be related to the average velocity and average depth over the cross-section. Instead of a linear relationship between the water depth and the depth average velocity, for the Jamuna River, the relation between velocity and the square root of the depth yields a good demarcation line between the erosion and deposition areas. This prediction method for erosion and deposition presented by the following Equations (1) to (3):

$$
\begin{gathered}
\text { Erosion: } u>\sqrt{h}-1.35 \\
\text { Transition: } \sqrt{h}-1.35 \leq u \leq \sqrt{h}-1.65 \\
\text { Deposition: } u<\sqrt{h}-1.65
\end{gathered}
$$

where, $h=$ water depth in meter and $u=$ depth average velocity in $\mathrm{m} / \mathrm{sec}$. Transition is defined as erosion/deposition $<1.0 \mathrm{~m}$.

To predict the erosion and depositions on the riverbed of the Jamuna River, 2012-13 cross-section data were used to estimate the depth average velocity and water depth at changing flow regime conditions after dredging.

\subsubsection{Method-II (Depth-Velocity \& Sediment Concentration Relationship)}

To predict the sediment transport process in the riverbed of the Jamuna River, 9 points were selected from the Sirajganj Hardpoint to downstream of the Jamuna 
Bridge near the Dhaleswari Offtake. A sediment transport predictor equation for the Jamuna River was referred to in the FAP 24: 1996 reports (FAP 24, 1996). This equation was derived in the River Survey Project using the Bangladesh Water Development Board (BWDB) data. In this equation, sediment concentration is estimated by the depth average velocity which is replaced by using Chezy's relation instead of using the weighting factor parameter $\theta$. The modified equation for estimating the sediment concentration is expressed in Equation (4):

$$
c=\frac{80}{1-\epsilon} * \sqrt{\Delta g D_{50}^{3}} *\left(\frac{1}{c^{2} \Delta D_{50}}\right)^{1.8} * \frac{u^{2.6}}{h}
$$

where, $C=$ depth-average concentration, Assuming value in FAP 24 study for relative density of Jamuna river, $\Delta=1.65, c=70 \mathrm{~m}^{1 / 2} / \mathrm{s}$ and Particle size of bed material, $D_{50}=0.2 \mathrm{~mm}$.

The following equation can be expressed in another form as Equation (5):

$$
c=1024 * \frac{u^{2.6}}{h}
$$

where $C$ is expressed in $\mathrm{mg} / \mathrm{L}$.

Here the roughness height for the river bedform not only depends on the heigh of bedforms but also depends on the shape of the bedform. This observation contradicts the previous observation (Klaassen et al., 1988). To estimate the average roughness and sediment transport, the effect of the bedform during the high flow may not be relevant, but for locations, it might have some influence in contributing to the local roughness. Here, it should be mentioned that apart from the high sediment concentration, there are some locations where the bedform is also prominent.

\subsection{Cross-Section Comparison}

Cross-section data of the Jamuna River were plotted from upstream of the Sirajganj Hardpoint to downstream of the Jamuna Bridge at 5 selected locations. Dredging was implemented during 2011-12 and 2012-13 and cross-sections were compared from 2010 to 2013 to determine the trend of shifting the river courses, changes in planform, and sedimentation process before and after dredging. In this analysis suspended sediment concentration and discharge are also related to the cross-sections. The rate of riverbank erosion and changing planform of the river course is also related to the rate of sediment concentration and discharges.

\subsection{Preparation of Matrix}

In natural rivers, there are always some uncertainties in estimating the relevant parameters due to their variation in space. A matrix is a combination of indicators, which will assist in the extraction of field information, compilation, and comparison of the data. An integrated approach was considered for the preparation of the erosion-sedimentation matrix, which would be based on analytical results and observed data using Method-I, Method-II, and cross-section comparison. 


\subsection{Satellite Image Analysis}

The channel planform analysis was performed based on the available satellite images (open source). Satellite images have been collected from the United States Geological Survey (USGS) database for the year 2000 to 2018. The river planform analysis facilitates in making out the changes of the river courses with time. It will further give an idea of the bankline migration and channel shifting patterns around the study area. From the analysis, the bank line of the different years has been delineated and superimposing the channels of different years. Based on this approach, a bankline shifting map and a channel incidence map around the study area of the Jamuna River have been prepared. These maps can support the initial planning and clear guidance for the possible long-term flow regime pattern of the river.

\section{Results and Discussion}

The changing morphology of the sand-bed braided Jamuna river is a great challenge for the sustainability of different river training works. This study investigated the unsteady flow pattern of the river as well as variations of riverbed elevation, bank line shifting, and sediment transport processes. The analytical results of this study are presented in the following subsections.

\subsection{Method-I (Depth-Velocity Relationship)}

The observed erosion and deposition in relation to depth and velocity is the result of a combination of different processes and is in principle based on physical laws. Processes involved in these relations are adaptation processes. The bed topography (cross-section) showed a correlation with the flow pattern. The variation in flow was primarily controlled by the erosion and depositing/sedimentation on the riverbed.

The numerical prediction of the erosion and deposition rate on the riverbed in the Jamuna River using Method-I at selected locations are shown in Figures 3(a)-(i). Results demonstrated that the right bank of the Sirajganj Hardpoint (Figure 3(a)) was favorable for sedimentation and at the same time left Bank (Figure 3(b)) was favorable for erosion. An importante note on this finding is that the scenario was occurred due to the position of sandbars upstream of the Sirajganj Hardpoint. Predicted sedimentation-erosion in the dredged channel revealed that erosion is likely to occur at the right Bank (Figure 3(c)) of the dredged channel whereas no changes were predicted at the left bank (Figure $3(d)$ ) of the dredged channel. This phenomenon was expected because the dredging alignment crossing through the existing sandbar/char (land) at that location.

Based on the geomorphological formation the maximum flow of the Jamuna River flowing through the right channel. Thus, the right channel of the upstream near the Jamuna Bridge tends to be eroded in the monsoon but seems to be deposited in the dry season which was also predicted by the simulation (Figure 3(e)). 


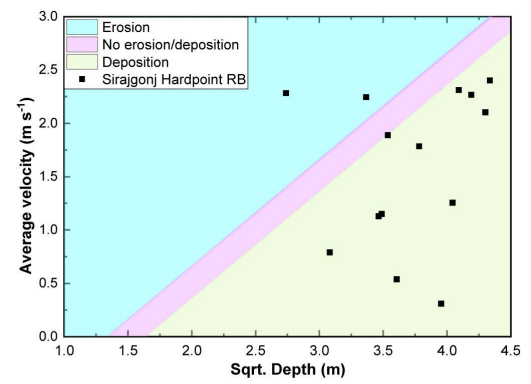

(a)

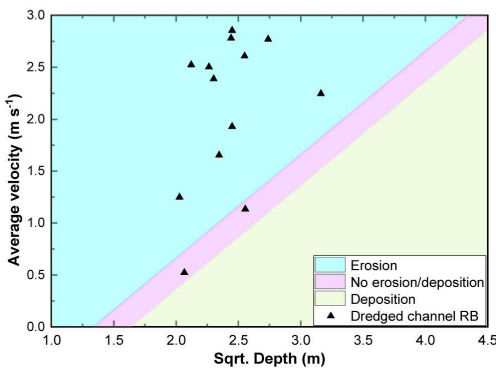

(c)

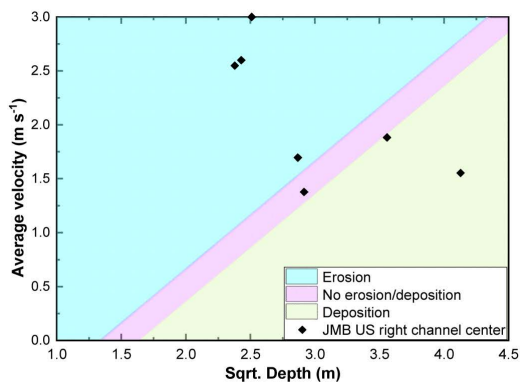

(e)

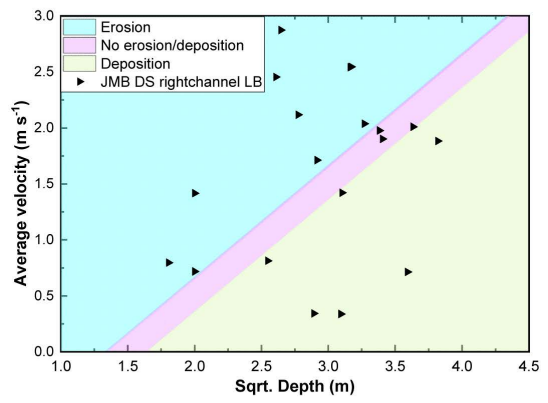

(g)

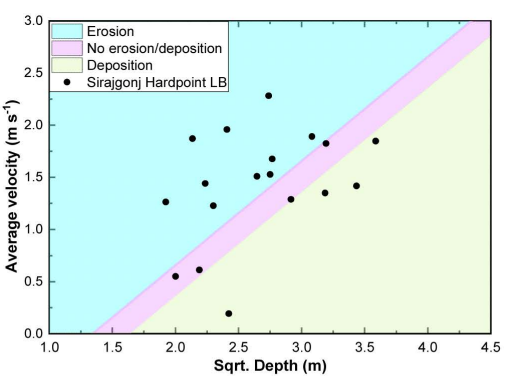

(b)

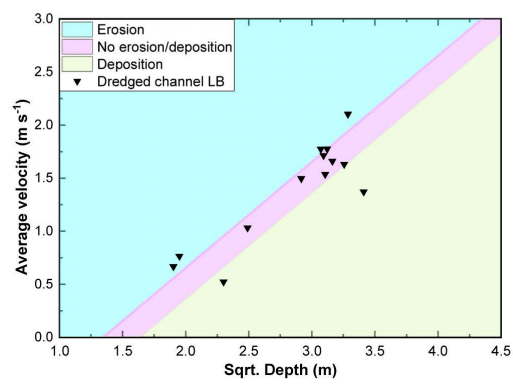

(d)

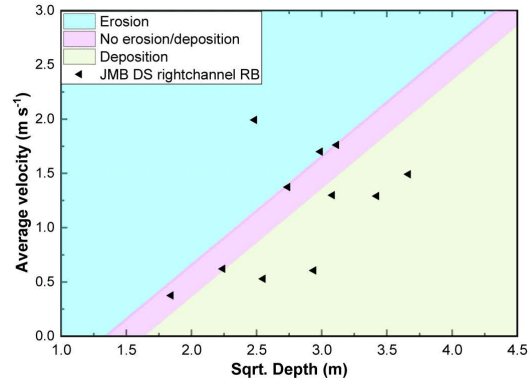

(f)

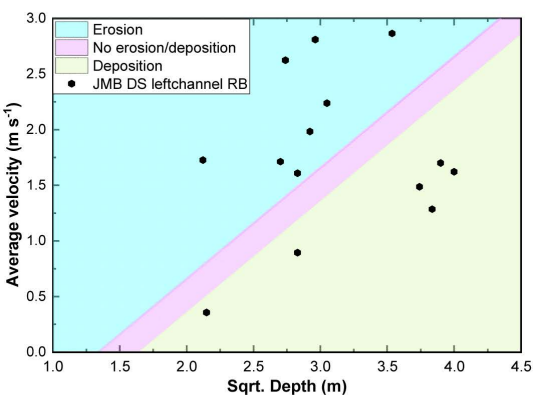

(h)

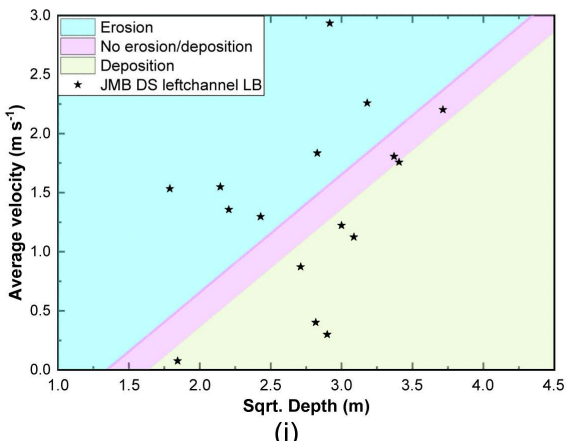

(i)

Figure 3. The predicted erosion and deposition pattern on the riverbed at different locations in the Jamuna River using Method-I during the period time in 2012-2013. 
Predicted average velocity at the right channel at the downstream (D/S) of the Jamuna Bridge appeared in the deposition zone for the right bank (Figure 3(f)), at the same time the left bank indicated possible erosion. This is because of the presence of high char (sandbar) on the left side of the channel. The Jamuna River is bifurcating by the right channel and the left channel just downstream of the Jamuna Bridge. The left channel at the downstream (D/S) of the Jamuna Bridge discharges the maximum flow during monsoon which plays the important role in erosion. However, the construction of the sand bar on the right side of the channel reduced the erosion and induced deposition. Results predicted and shown in Figure 3(h) to Figure 3(i) indicated both the right and left banks of the left channel at the downstream (D/S) of the Jamuna Bridge were dominated by erosion. A fewer deposition for both banks reflects the presence of the sandbar at that section.

\subsection{Method-II (Depth-Velocity \& Sediment Concentration Relationship)}

Figures 4(a)-(i) represented the actual and predicted sediment concentration at different water depths at 9 selected locations using Method-II.

Model outputs indicated a strong relation of the predicted and observed sediment concentration with the water level during the analyzed period. For example, Figure 4(a) and Figure 4(b) show that the rate of observed sediment concentration is higher than the predicted sediment concentration during the analyzing period at both left and right banks of the Sirjganj Hardpoint. However, in the month of June to July and October to November 2012, the rate of predicted sediment concentration is higher than the observed sediment concentration. The result denoted that the sedimentation occurred round the year at both banks, but the erosion of the riverbank is occurred only at rising and falling water level conditions. This finding was also supported by the measured cross-sections (shown in Figure 5(a), in Section 4.3). Observed sediment concentration for both banks of the dredged channel of the Jamuna River demonstrated higher values than predicted (Figure 4(c) and Figure 4(d)).

This is important to mention that the dredging alignment passing through the high char/sandbar (land) in this location allowed the loose soil material to transport at the char when the flows were passing through the dredged channel. From the practical point of view, the right bank of the dredged channel was eroded due to high flow velocity, and the left bank was silted up due to slope failure of both banks. Higher observed sediment concentration rate compared to the predicted (shown in Figure 4(e)) at upstream (U/S) of the Jamuna Bridge (center of the right channel) in June 2012 was expected due to the maximum flows were passing through the channel in the monsoon. So, the channel was eroded in the monsoon, but the channel was silted up in all seasons as dry, pre-monsoon, and post-monsoon, which was also revealed by the cross-section comparisons as shown in Figure 5(c) and Figure 5(d), in section 4.3. The maximum flow at the downstream of the Jamuna Bridge used to pass through 


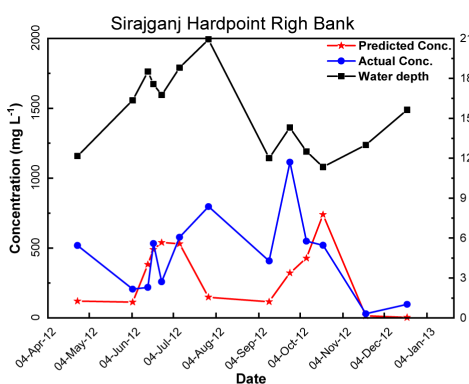

(a)

Dreged Channel Right Bank

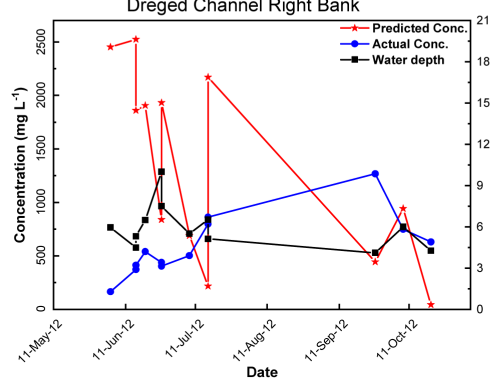

(c)

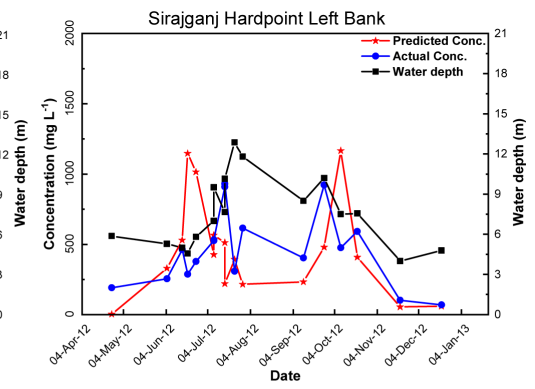

(b)

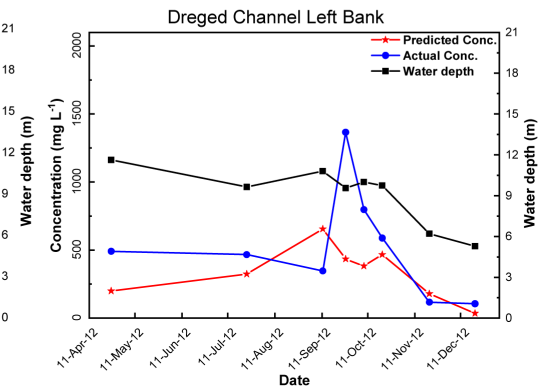

(d)

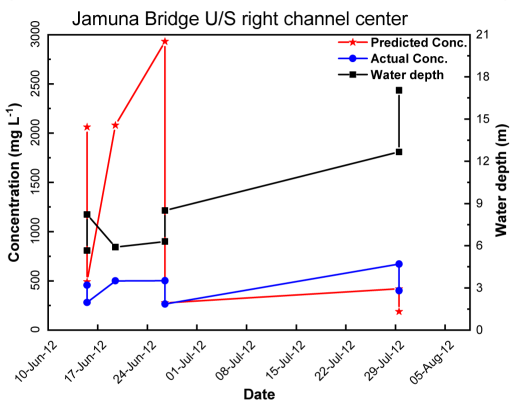

(e)

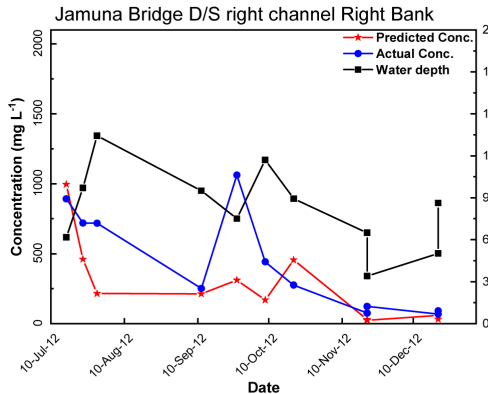

(f)

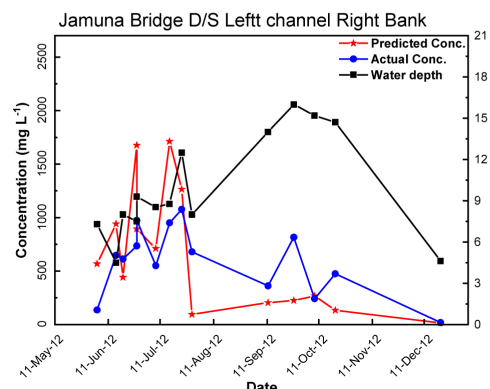

(h)

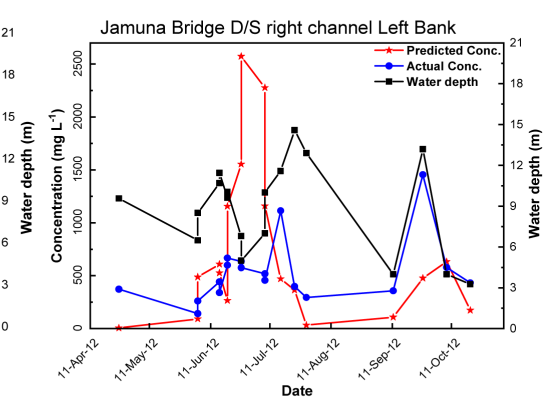

(g)

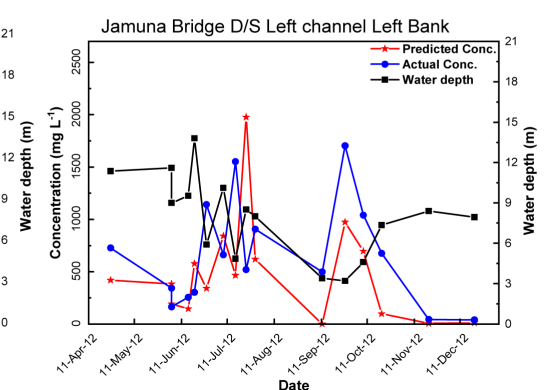

(i)

Figure 4. Observed and predicted sediment concentrations $(\mathrm{mg} / \mathrm{L})$ with water depth at different locations during various periods in 2012-2013. 


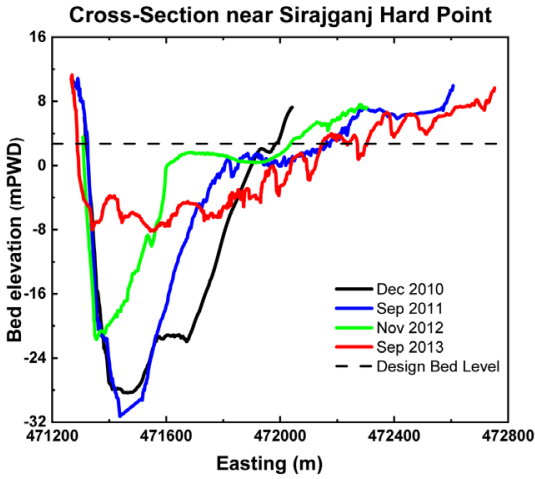

(a)

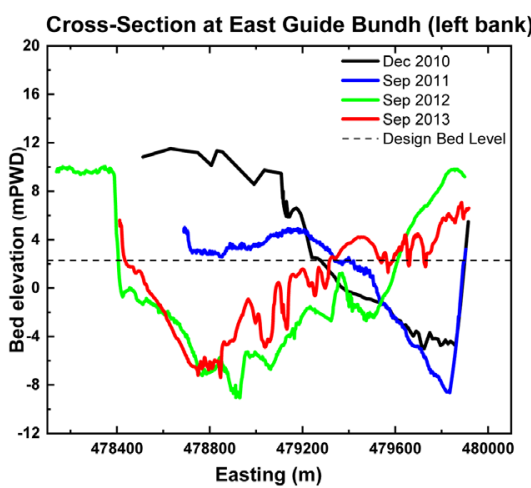

(c)

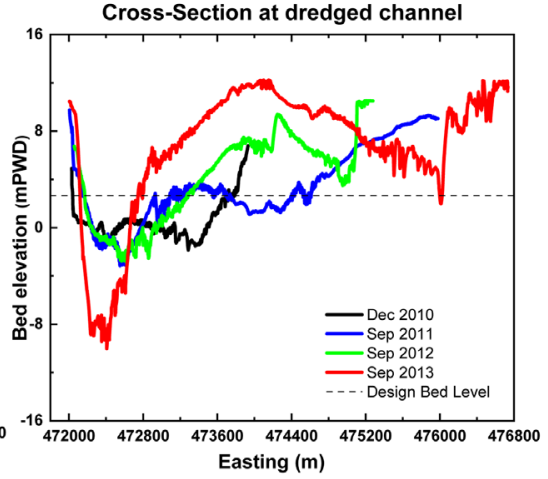

(b)

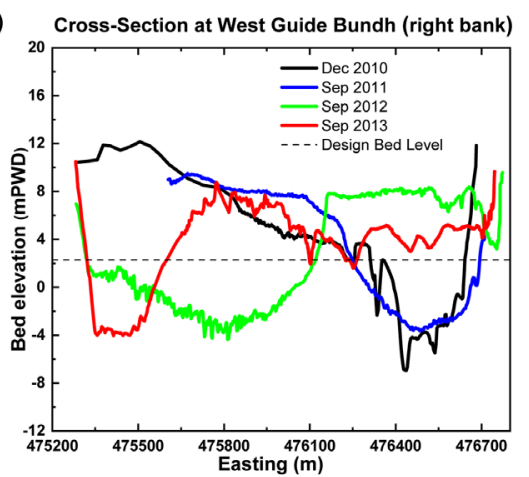

(d)

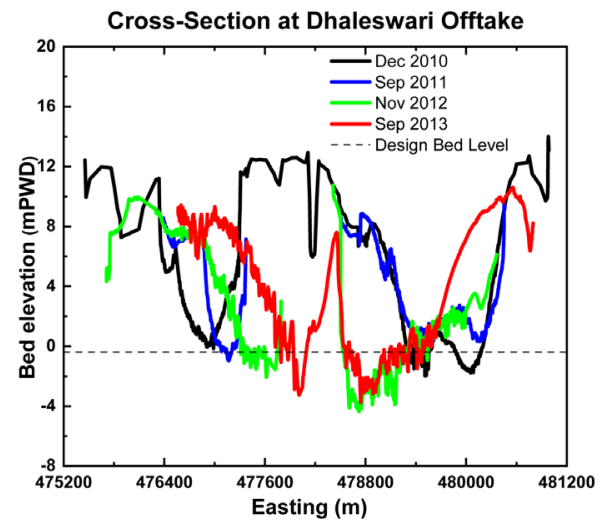

(e)

Figure 5. Cross-sections of Jamuna River near/at (a) Sirajganj Hardpoint, (b) dredged channel, (c) East guide bundh, (d) West guide bundh, and (e) Dhaleswari Offtake.

the left channel, thus, it is quite difficult to divide it as the left or right channel during the monsoon. Moreover, both banks of the right channel were silted up round the year. At the right channel, the rate of observed sediment concentration was mostly higher than the predicted (Figure 4(f) and Figure 4(g)) for both right and left banks. Similar characteristics were observed (Figure 4(h) and Figure 4(i)) at the right and left bank on the left channel of the downstream $(D / S)$ of the Jamuna Bridge, except in the monsoon. Numerical results also indicated that both banks of this channel were silted up round the year but both banks may erode only in the monsoon. Cross-sections at this channel over the 
analyzed duration were compared and shown in Figure 5(e), in Section 4.3.

\subsection{Cross-Section Comparison}

Cross-section data were plotted from upstream of the Sirajganj Hardpoint to downstream of the Jamuna Bridge in the period 2010-2013 at five selected locations are shown in Figures 5(a)-(e).

Those data represented the trend of shifting of the river courses, changes in planform, and sedimentation process before and after the dredging works. An insignificant impact of dredging on cross-sections was evident from the cross-section comparisons at the reach considered for this study. Similar scenarios were also predicted by numerical models described in Section 3.1. A minor rate of sedimentation was observed around the Sirajganj Hardpoint at the beginning of dredging. Most importantly, the scour depth at the Sirajgonj Hardpoint was reduced to a maximum of $5 \mathrm{~m}$. Initially, a few percentages of water flow through the dredged channel but after one year of flooding, it was observed that the dredged channel silted up to $60 \%-80 \%$. It was also seen that the sedimentation was higher, where the dredging alignment passing through the existing char. Cross-section comparison also presented the change in bed profile of the East Guide Bundh (EGB) and the West Guide Bundh (WGB) (locations are in Figure 6). Near the East Guide Bundh of the Jamuna Bridge, it was found that the sedimentation was higher near the bank channel.

\subsection{Comparison of Model-Predicted Erosion-Sedimentation with Field Data}

Interrelation among erosion, sedimentation, and sediment concentration was
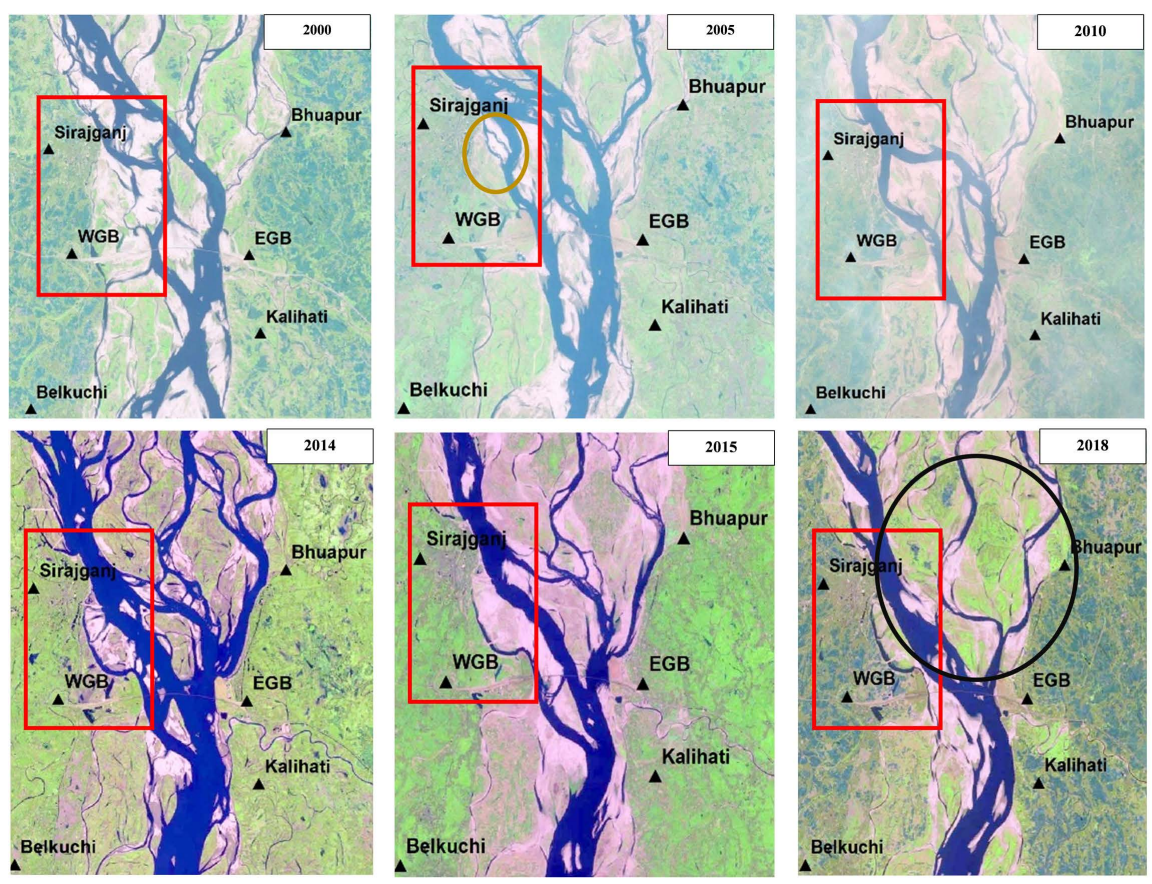

Figure 6. Planform of the Jamuna River for the year 2000 to 2018. 
well established from the field data and displayed similar behavior in numerical models. However, model predictions for two sites (the Dredged Channel Left Bank and the Jamuna Bridge D/S Right Channel Left Bank) were showed different phenomena due to the influence of local hydro morphological parameters (depth, velocity, and sediment concentration, etc.) and upstream morph-dynamic processes. Furthermore, equations used in the above analysis are one dimensional, while the local morpho-dynamic processes that are very much dependent on the morphology is three dimensional. It was also seen that the flow in the Jamuna River, especially during the high flow is not in equilibrium with the riverbed topography, but rather is governed by upstream conditions and the momentum of the flow. Analyzed results using Method-I, Method-II, and cross-sections comparison are summarized in Table 1.

\subsection{Satellite Image Analysis}

Satellite images from 2000 to 2018 were considered for the planform analysis, to observe the change in the flow pattern of the Jamuna river before and after the dredging. However, the dredging of the Jamuna river was implemented in the year 2011-2012 and the flow diverting structures were constructed in the year 2013-2014. The planform analysis includes the changes in the width of the river/channel, bank line shifting, channel migration tendency, and incidence map

Table 1. Erosion and deposition matrix at nine locations using Method-I, Method-II, and also cross-sections comparison.

\begin{tabular}{|c|c|c|c|c|c|c|c|c|}
\hline \multirow{3}{*}{ Sample Location } & \multirow{3}{*}{ Duration } & \multicolumn{3}{|c|}{ Method-I } & \multicolumn{3}{|c|}{ Method-II } & \multirow{3}{*}{$\begin{array}{c}\text { Field } \\
\text { observation } \\
\text { and } \\
\text { cross-section } \\
\text { comparison }\end{array}$} \\
\hline & & Erosion & Deposition & $\begin{array}{c}\text { No } \\
\text { erosion/Deposition }\end{array}$ & Erosion & Deposition & $\begin{array}{c}\text { No } \\
\text { erosion/Deposition }\end{array}$ & \\
\hline & & $(\%)$ & $(\%)$ & $(\%)$ & $(\%)$ & $(\%)$ & $(\%)$ & \\
\hline $\begin{array}{c}\text { Sirajganj } \\
\text { Hardpoint RB }\end{array}$ & $\begin{array}{l}\text { April } 2012 \text { to } \\
\text { January } 2013\end{array}$ & 7 & 79 & 14 & 20 & 60 & 20 & Deposition \\
\hline $\begin{array}{c}\text { Sirajganj } \\
\text { Hardpoint LB }\end{array}$ & $\begin{array}{l}\text { April } 2012 \text { to } \\
\text { January } 2013\end{array}$ & 56 & 26 & 18 & 16 & 56 & 28 & Deposition \\
\hline $\begin{array}{c}\text { Dredged } \\
\text { channel RB }\end{array}$ & $\begin{array}{c}\text { May } 2012 \text { to } \\
\text { November } 2012\end{array}$ & 84 & 0 & 16 & 69 & 23 & 8 & Erosion \\
\hline $\begin{array}{c}\text { Dredged } \\
\text { channel LB }\end{array}$ & $\begin{array}{l}\text { April } 2012 \text { to } \\
\text { January, } 2013\end{array}$ & 23 & 15 & 62 & 8 & 75 & 17 & Erosion \\
\hline $\begin{array}{l}\text { Jamuna Bridge U/S } \\
\text { right channel Center }\end{array}$ & $\begin{array}{l}\text { June } 2012 \text { to } \\
\text { August } 2012\end{array}$ & 58 & 14 & 28 & 44 & 14 & 42 & Erosion \\
\hline $\begin{array}{l}\text { Jamuna Bridge } \mathrm{D} / \mathrm{S} \\
\text { right channel } \mathrm{RB}\end{array}$ & $\begin{array}{l}\text { June } 2012 \text { to } \\
\text { January } 2013\end{array}$ & 10 & 45 & 45 & 9 & 55 & 36 & Deposition \\
\hline $\begin{array}{c}\text { Jamuna Bridge D/S } \\
\text { right channel LB }\end{array}$ & $\begin{array}{c}\text { April } 2012 \text { to } \\
\text { November } 2012\end{array}$ & 48 & 26 & 26 & 40 & 35 & 25 & Erosion \\
\hline $\begin{array}{c}\text { Jamuna Bridge D/S } \\
\text { left channel RB }\end{array}$ & $\begin{array}{l}\text { May } 2012 \text { to } \\
\text { January } 2013\end{array}$ & 57 & 43 & 0 & 25 & 63 & 12 & Erosion \\
\hline $\begin{array}{l}\text { Jamuna Bridge D/S } \\
\text { left channel LB }\end{array}$ & $\begin{array}{l}\text { April } 2012 \text { to } \\
\text { January } 2013\end{array}$ & 44 & 38 & 18 & 19 & 56 & 25 & Deposition \\
\hline
\end{tabular}


of the river/channel in the vicinity of the study reach (around Jamuna Bridge and Sirajganj Hard Point area). Planform analysis is shown in Figure 6 and digitized bank lines with channel incidence maps of the Jamuna River is presented in Figure 7(a) and Figure 7(b), respectively.

A dry season time-series satellite images during the same period (2000-2018) were used to identify the bank line migration within the study reach. Digitization was conducted from the georeferenced images to delineate the bank line, which separates the river from the bank. Major bank line shifting, and channel formation were observed in between the Sirajganj Hardpoint and West Guide Bundh (right bank) of the Jamuna Bridge from the year 2000 to 2010. On the other hand, channel shifting was observed from 2014 to 2018 in that location after the construction of the flow diverting structures (Groin/Cross-ber). However, in the incidence map the percentage of channel persistence varied from $40 \%$ to $60 \%, 60 \%$ to $80 \%$, and less percentage of $80 \%$ to $100 \%$ around the study reach. Moreover, the channel incidence map and bank line shifting map of the Jamuna River covering the study reach for the year 2000 to 2018 shows an unstable path in the upstream and the downstream of the study reach and indicates a very dynamic river morphology.
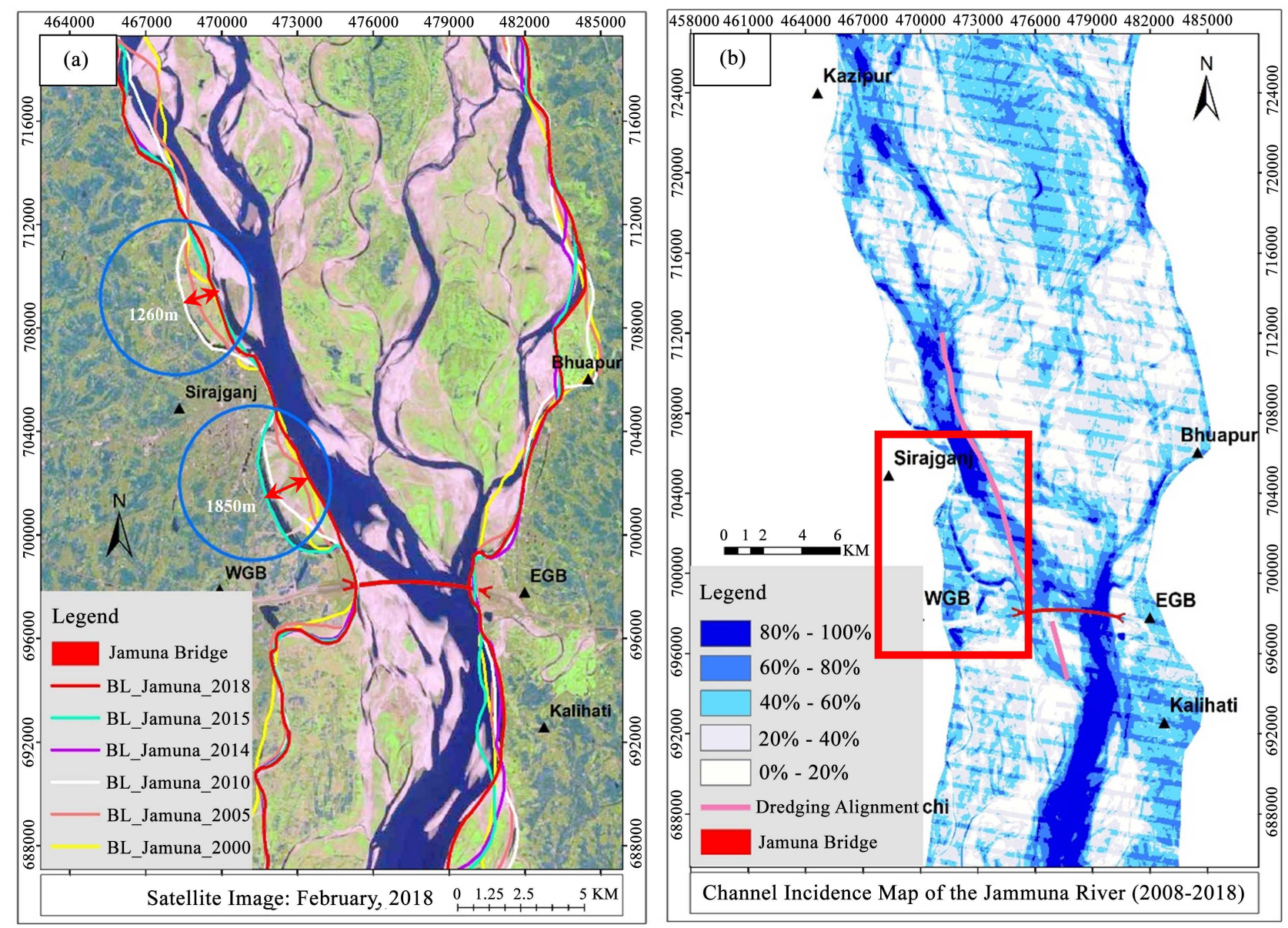

Figure 7. (a) Digitized bank lines and (b) Channel Incidence map of the Jamuna River. 
Digitized banklines (Figure 7(a)) and channel incidence map (Figure 7(b)) were analyzed over years from 2000 to 2018. The right channel between Sirajganj Hardpoint and West Guide Bundh (right bank) showed an insignificant change in the year 2000. However, the channel formation was started in the year 2005 (marked with the yellow circle). A narrow channel transformed into a prominent channel from 2005 to 2010 with the detachment from the char near to the right bank. The right channel near the bend of the Sirajganj hardpoint eroded at the maximum curvature in 2010 and moved outward from the bank which follows the characteristics of the meandering river. Bank erosion was measured around 1850 m which occurred from 2000 to 2010 in between Sirajganj Hardpoint and West Guide Bundh (right bank).

Due to the presence of low land/char at the upstream, flows hit the right bank between the Sirajganj Hardpoint and the West Guide Bundh (right bank). The right channel of the study reach was wider from 2014-2018 compared to 2000-2010. During the year 2014 to 2018, the right channel carried the maximum discharge, and flows were passed through the guiding structures. As a result, the flowing channel near the training structures performed as a straight channel within the study reach due to the construction of flow diverting structures i.e., groin, crossbar, etc. between the Sirajganj Hardpoint and West Guide Bundh (right bank). The left channel was narrowed down, and the char was moving upstream to downstream both laterally and longitudinally. It was also visible from the image analysis that the right channel was prominent, and the study reach was performed as a single channel. It should be noted that after the construction of the groin/crossbar, the bend between Sirajganj Hardpoint and West Guide Bundh (right bank) became reclaimed. It was also seen that the channel adjacent to the East Guide Bundh (left bank) carried a dominant discharge and erosion occurred at the left bank near Kalihati shown in Figure 7(a).

\section{Conclusions}

River channels tend to a dynamic equilibrium driven by the dynamics of river flow and sediment transport. River dredging can influence the natural drivers of the channel morphology as well as the hydrodynamic process. The present study potentially investigated the effect of river dredging on the fluvial geomorphology of a reach near the Jamuna Bridge in the Jamuna River. The water depth, flow velocity, and sediment concentration relationships were utilized in a numerical framework to explore the fluvial geomorphological characteristics. Model outputs anticipated the potential erosion and sedimentation phenomenon at distinct sections which were parallel with the observational field data. However, the persisting impact of dredging was insignificant to the change in river cross-sections. Cross-sectional data from field measurement indicated that the channel near the Sirajganj Hardpoint shifts towards East (left) and the existing channel near the Sirajganj Hardpoint was silted up within a year of monsoon flooding which proves that the impact of dredging was insignificant. It was also observed that the sediment concentration was higher, where the dredging alignment crossed 
through the existing sandbar/char. These phenomena governed due to the hydraulic condition and morphological parameters were consistent around the area even after the dredging. A long-term satellite image analysis of the planform in the study reach explored that the bank line shifting and channel formation started between 2000 to 2010 . However, the channel shifting process was accelerated after the construction of the flow diverting structures (Groin/Cross-ber) from 2014 to 2018. Also, the right channel of the study reach performed as a single channel which carried the maximum discharge adjacent to the East Guide Bundh (left bank), and erosion occurred at the left bank near Kalihati. Besides, the dynamics of the river morphology was investigated from the deviation in channel persistence in the incidence map. This study gave the insight to design the river training works under the influence of dredging and the acceptability of the sediment-erosion modeling approach for similar rivers.

\section{Acknowledgements}

The authors are thankful to the Project Director, Capital (Pilot) Dredging of River System of Bangladesh, for providing the project data and necessary support to write up this research article. Support and permission provided by the Institute of Water Modeling (IWM); Bangladesh are also gratefully acknowledged.

\section{Conflicts of Interest}

The authors declare no conflicts of interest regarding the publication of this paper.

\section{References}

Akhter, S., Eibek, K. U., Islam, S., Islam, A. R. M. T., Chu, R., \& Shuanghe, S. (2019). Predicting Spatiotemporal Changes of Channel Morphology in the Reach of Teesta River, Bangladesh Using GIS and ARIMA Modeling. Quaternary International, 513, 80-94. https://doi.org/10.1016/j.quaint.2019.01.022

Billah, M. M. (2018). Mapping and Monitoring Erosion-Accretion in an Alluvial River Using Satellite Imagery-The River Bank Changes of the Padma River in Bangladesh. Quaestiones Geographicae, 37, 87-95. https://doi.org/10.2478/quageo-2018-0027

Bose, I., \& Navera, U. K. (2018). Analysis on River Bank Erosion-Accretion of Dharla River (Bangladesh) Using Multi-Temporal Satellite Images. AGU Fall Meeting Abstracts, Washington DC, 10-14 December 2018, H12H-42.

Campagnol, J., Ballio, F., Hosseini Sadabadi, S. A., \& Sazadul, H. (2014). Particle Motion of Bed-Load Sediment Moving over a Smooth Bed. Proceedings of River Flow, Lausanne, 3-5 September 2014, 763-769. https://doi.org/10.1201/b17133-105

Chowdhury, A. H., \& Kabir, M. (1991). Socioeconomic and Demographic Characteristics of Displaces in Bhola and Kazipur: A Comparative Study. Riverbank Erosion Impact Study, Jahangirnagar University, 1,1 .

Elahi, K. M. (1991). Riverbank Erosion, Flood Hazard and Population Displacement in Bangladesh: An Overview. Riverbank Erosion, Flood Hazard and Population Displacement in Bangladesh Dhaka (p. 364). Riverbank Erosion Impact Study (REIS), Jahangirnagar University. 
Ety, N. J., \& Rashid, M. S. (2019). Spatiotemporal Variability of Erosion and Accretion in Ganges River Using GIS and RS: A Comparative Study Overlapping Rennell's Map of 1760s. Environment, Development and Sustainability, 22, 3757-3775. https://doi.org/10.1007/s10668-019-00317-4

FAP 1 (1993). River Training Studies of the Brahmaputra River. Annex 2: Morphology: Draft Final Report. Dhaka: Flood Action Plan, Flood Plan Coordination Organization (FPCO).

FAP 24 (1996). River Survey Project: Morphological Characteristics of Main Rivers of Bangladesh. Final Report-Annex 5. Dhaka: Flood Action Plan, Water Resources Planning Organization (WARPO).

Ferdous, M. R., Wesselink, A., Brandimarte, L., Slager, K., Zwarteveen, M., \& Di Baldassarre, G. (2019). The Costs of Living with Floods in the Jamuna Floodplain in Bangladesh. Water, 11, 1238. https://doi.org/10.3390/w11061238

Fischer, S., Pietroń, J., Bring, A., Thorslund, J., \& Jarsjö, J. (2017). Present to Future Sediment Transport of the Brahmaputra River: Reducing Uncertainty in Predictions and Management. Regional Environmental Change, 17, 515-526.

https://doi.org/10.1007/s10113-016-1039-7

Gob, F., Houbrechts, G., Hiver, J., \& Petit, F. (2005). River Dredging, Channel Dynamics and Bedload Transport in an Incised Meandering River (the River Semois, Belgium). River Research and Applications, 21, 791-804. https://doi.org/10.1002/rra.883

Goodbred Jr., S. L., Paolo, P. M., Ullah, M. S., Pate, R. D., Khan, S. R., Kuehl, S. A., Singh, S. K., \& Rahaman, W. (2014). Piecing Together the Ganges-Brahmaputra-Meghna River Delta: Use of Sediment Provenance to Reconstruct the History and Interaction of Multiple Fluvial Systems during Holocene Delta Evolution. Bulletin, 126, 1495-1510. https://doi.org/10.1130/B30965.1

Hasan, M. S., \& Islam, R. (2010). Suitability of Padma River Water for Domestic Supply in Rajshahi City Corporation Areas. ULAB Journal of Science and Engineering, 1, 48-53.

Hasan, M. S., \& Kabir, M. I. (2014). Feasibility of Natore Rubber Dam on Mahanonda River in Bangladesh and Its Performance on Irrigation. American Journal of Engineering Research, 3, 27-34.

Hasan, M. S. (2013). Analysis of Sediment Particle Motion on a Smooth Bed. Thesis, Milano: Politecnico di Milano.

Islam, M. N., Biswas, R. N., Shanta, S. R., Islam, R., \& Jakariya, M. (2019). Morphological Dynamics of the Jamuna River in Kazipur Subdistrict. Earth Systems and Environment, 3, 73-81. https://doi.org/10.1007/s41748-018-0078-2

Islam, M. R., Begum, S. F., Yamaguchi, Y., \& Ogawa, K. (1999). The Ganges and Brahmaputra Rivers in Bangladesh: Basin Denudation and Sedimentation. Hydrological Processes, 13, 2907-2923. https://doi.org/10.1002/(SICI)1099-1085(19991215)13:17<2907::AID-HYP906>3.0.CO; $\underline{2-\mathrm{E}}$

Islam, M. R., Yamaguchi, Y., \& Ogawa, K. (2001). Suspended Sediment in the Ganges and Brahmaputra Rivers in Bangladesh: Observation from TM and AVHRR Data. Hydrological Processes, 15, 493-509. https://doi.org/10.1002/hyp.165

Kafi, M. A. H., Hossain, M. S., Chowdhury, A. K., Islam, M. T., \& Masud, M. S. (2018). Assessment of Long Term Evolution of Morphodynamics of the Kalni-Kushiyara River System in Bangladesh Using One Dimensional Morphological Model. Journal of Civil Engineering (IEB), 46, 21-30. 
Kanga, S., Meraj, G., Das, B., Farooq, M., Chaudhuri, S., \& Singh, S. K. (2020). Modeling the Spatial Pattern of Sediment Flow in Lower Hugli Estuary, West Bengal, India by Quantifying Suspended Sediment Concentration (SSC) and Depth Conditions Using Geoinformatics. Applied Computing and Geosciences, 8, Article ID: 100043.

https://doi.org/10.1016/j.acags.2020.100043

Kasprak, A., Brasington, J., Hafen, K., Williams, R. D., \& Wheaton, J. M. (2019). Modelling Braided River Morphodynamics Using a Particle Travel Length Framework. Earth Surface Dynamics, 7, 247-274.

https://doi.org/10.5194/esurf-7-247-2019

Khan, I., Ahammad, M., \& Sarker, S. (2014). A Study on River Bank Erosion of Jamuna River Using GIS and Remote Sensing Technology. International Journal of Engineering Development and Research, 2, 3365-3371.

Klaassen, G., Vermeer, K., \& Uddin, N. (1988). Sedimentological Processes in the Jamuna (Lower Brahmaputra) River, Bangladesh. In Proceedings of the International Conference on Fluvial Hydraulics (pp. 381-394). Budapest: International Association of Hydraulic Research.

Mutton, D., \& Haque, C. E. (2004). Human Vulnerability, Dislocation and Resettlement: Adaptation Processes of River-Bank Erosion-Induced Displacees in Bangladesh. Disasters, 28, 41-62. https://doi.org/10.1111/j.0361-3666.2004.00242.x

Nardin, W., Vona, I., \& Fagherazzi, S. (2020). Sediment Deposition Affects Mangrove Forests in the Mekong Delta, Vietnam. Continental Shelf Research, 213, Article ID: 104319. https://doi.org/10.1016/j.csr.2020.104319

Ophra, S. J., Begum, S., Islam, R., \& Islam, M. N. (2018). Assessment of Bank Erosion and Channel Shifting of Padma River in Bangladesh Using RS and GIS Techniques. Spatial Information Research, 26, 599-605. https://doi.org/10.1007/s41324-018-0202-2

Rahman, M., Dustegir, M., Karim, R., Haque, A., Nicholls, R. J., Darby, S. E., Nakagawa, H., Hossain, M., Dunn, F. E., \& Akter, M. (2018). Recent Sediment Flux to the Ganges-Brahmaputra-Meghna Delta System. Science of the Total Environment, 643, 1054-1064. https://doi.org/10.1016/j.scitotenv.2018.06.147

Rogers, K., \& Overeem, I. (2017). Doomed to Drown Sediment Dynamics in the Human-Controlled Floodplains of the Active Bengal Delta. Elementa: Science of the Anthropocene, 5, 66. https://doi.org/10.1525/elementa.250

Sambrook Smith, G. H., Best, J., Bristow, C., \& Petts, G. (2006). Braided Rivers: Process, Deposits, Ecology and Management. Hoboken, NJ: Wiley. https://doi.org/10.1002/9781444304374

Sarker, M. H., Akter, J., Ferdous, M., \& Noor, F. (2011). Sediment Dispersal Processes and Management in Coping with Climate Change in the Meghna Estuary, Bangladesh. In Proceedings of the Workshop on Sediment Problems and Sediment Management in Asian River Basins (pp. 203-218). Publication 349, Hyderabad: IAHS.

Sarker, M. H., Thorne, C. R., Aktar, M. N., \& Ferdous, M. R. (2014). Morpho-Dynamics of the Brahmaputra-Jamuna River, Bangladesh. Geomorphology, 215, 45-59.

https://doi.org/10.1016/j.geomorph.2013.07.025

Team C-BJE (1991). Study Report on Flood Control and River Training Project on the Brahmaputra River in Bangladesh. Vol. I, Analysis of Hydrology and River Morphology of the Brahmaputra River.

Thompson, A., She, Y., Oberhagemann, K., \& Haque, A. (2018). The Behavior of Self-Geotextile Bag Aprons-Latest Investigations from the Lower Brahmaputra in Bangladesh. Scour and Erosion IX: Proceedings of the 9th International Conference on Scour and Erosion, Taipei, 5-8 November 2018, 167.

Uddin, M. N., \& Rahman, M. M. (2012). Flow and Erosion at a Bend in the Braided Ja- 
muna River. International Journal of Sediment Research, 27, 498-509. https://doi.org/10.1016/S1001-6279(13)60008-6

Valentine, L., Wilson, C., Rogers, K., Carrico, A., Donato, K., \& Gilligan, J. (2018). Sediment Accretion and Erosion in Poldered and Non-Poldered Regions within the Ganges-Brahmaputra-Meghna Delta, Bangladesh: Implications for River Channel Migration and Flood Risk. AGU Fall Meeting Abstracts, Washington DC, 10-14 December 2018, GC53D-0991.

Van Rijn, L. C. (2005). Principles of Sedimentation and Erosion Engineering in Rivers, Estuaries and Coastal Seas Including Mathematical Modelling Package (Toolkit on CD-ROM). Aqua Publications.

Zinger, J. A., Rhoads, B. L., \& Best, J. L. (2011). Extreme Sediment Pulses Generated by Bend Cutoffs along a Large Meandering River. Nature Geoscience, 4, 675-678.

https://doi.org/10.1038/ngeo1260 